\title{
Harmonization and Synchronization of Laws Related to Management Authority of Coastal Marine Areas
}

\author{
Khelda Ayunita $^{1 *}$, Achmad Ruslan², Abd Razak², Hamzah Halim² \\ ${ }^{1}$ Doctoral Student, Faculty of Law, Hasanuddin University, Indonesia \\ ${ }^{2}$ Professor, Faculty of Law, Hasanuddin University, Indonesia
}

DOI: $10.36348 /$ sijlcj.2020.v03i04.008

| Received: 02.04.2020 | Accepted: 09.04.2020 | Published: 14.04.2020

*Corresponding author: Khelda Ayunita

Abstract

The purpose of this study was to harmonization of laws concerning management of coastal marine areas and synchronization of regulations concerning management of coastal marine areas. This type of research is normative legal research, using a conceptual approach and a statute approach. The legal materials used in this study consist of primary, secondary and tertiary legal materials. The legal material that has been described in accordance with the main problem is then distributed, explored and then given an argument so that the whole forms a logically interconnected whole about the disclosure of logical rationale and the ontological basis for the issuance of laws governing coastal marine areas. The results of this study indicate that the laws and regulations are not synchronous, which means that they are not in harmony. The disharmony is very influential on the relationship of governmental authority. Because the relationship between the Government and the Regional Government should be synergized with each other in: (a) Carrying out tasks that have been attributed to the legislation, (b) Utilization of natural resources, (c) Granting of licenses, (d) Distribution of Results, (e) Determination of boundaries the region. As for the efforts taken, the government immediately made a norm as mandated in Law No. 23 Year 2014. Which then established the Regional Regulation. The substance of the PP and Perda emphasizes the portion of the Regency/City.

Keywords: coastal sea area, harmonization and synchronization, management authority.

Copyright @ 2020: This is an open-access article distributed under the terms of the Creative Commons Attribution license which permits unrestricted use, distribution, and reproduction in any medium for non-commercial use (NonCommercial, or CC-BY-NC) provided the original author and source are credited.

\section{INTRODUCTION}

The state as an organization of power has occupied a central position in the realm of the collective life of modern humans, the state is no longer seen only as an absolute entity, in which all stakeholders supporting the existence of the state must absolutely bow to the (ruler) state without reserve. However, on the contrary the state must follow the total rhythm of all the elements that constitute the state, especially the people or citizens of the country concerned. The state in this case must be a means of citizens to achieve the goals of human life in the nation's society, for example ensuring the security, justice and the highest welfare of the people themselves. Because the people are state entities that originally came from a collection of nations which united themselves into a state. For example: the United States of America came from various national breeds from Europea. The Swiss have 3 (three) kinds of languages that are equally strong. The Indonesian people have a variety of tribes, languages, customs and customs and religions [1]. Even though in a country people have different cultures, different languages, different tribes and religions, but human society is meant to have shared ideals and a shared determination to live together in a political or state unity.

In the aspect of administrative law, good governance cannot be separated from the authority owned and used by the government. Prajudi Atmosudirdjo differentiates between competence and authority which in administrative law differ in their understanding, although in practice the difference is not too felt. Authority is what is called formal power that comes from legislative power. While the authority is the delegation of some powers to take legal action [2]. In the Dutch administrative law literature, the issue of authority has always been an important and initial part of administrative law because the object of administrative law is the authority of government (bestuurs bevoegdheid) [3]. In the concept of public law, authority is a core concept in state and administrative law. In constitutional law, authority is described as legal power (rechtsmacht). So in the 
concept of public law, authority relates to the rule of law [4].

The history of local governance in Indonesia, decentralization and centralization have shifted several times. There are many factors that influence the ups and downs of decentralization, especially the nature of state power (central government) whether moving in a democratic or authoritarian direction. However, the shift that occurred must of course remain in the corridor of the 1945 Constitution of the Republic of Indonesia as the highest law. According to the concept of a unitary state decentralization comes from centralization. However, on the other hand decentralization and regional autonomy are provisions of the 1945 Constitution of the Republic of Indonesia.

This means that the unitary state must be run in tandem with regional autonomy. Centralization must not eliminate the existence of regional autonomy as constitutional mandate. In Law Number 23 Year 2014 concerning Regional Government, there is a tendency towards centralization. These trends can be identified both in terms of the concept of the distribution of functions, the authority to form regional regulations, as well as in the distribution of authority, especially for the management of natural resources, forestry, and mining [5]. The preamble of Law No. 23 Year 2014 states that the efficiency and effectiveness of the administration of regional government need to be improved by paying more attention to aspects of the relationship between the central and regional governments and regions, the potential and diversity of the region, as well as the opportunities and challenges of global competition in the unity of the state governance system.

Legislation as a legal product becomes a very important tool in the implementation of state life [6]. The issuance of Law No. 23 Year 2014 has an impact on autonomy in the management of coastal and small islands. Article 27 of Law No. 23 Year 2014. Management of marine resources fully under the authority of the provincial area. Article 27 paragraph (1) of Law No. 23 Year 2014 revokes the authority of regencies/cities in the management of marine resources. The authority of a provincial region to manage resources in a sea area no more than 12 (twelve) nautical miles is measured from the base line towards the open sea and/or towards archipelagic waters (Article 27 paragraph (3) of Law 23 Year 2014). This article strengthens the granting of authority to the Provincial Government, where previously there was the authority of the Regency/City Government as far as 4 (four) nautical miles as stipulated in Article 18 paragraph (4) of Law 32 Year 2004, which states that the authority to manage resources in the sea area is as referred to in paragraph (3) a maximum of 12 (twelve) nautical miles measured from the coastline towards the high seas and/or towards archipelagic waters for the province and
$1 / 3$ (one third) of the province's jurisdiction for regencies/cities.

In the case of the division of affairs between the Central Government, the Provincial Region and the Regency/City Region specifically in the maritime and fisheries sector which is regulated by law there is no granting of management authority to the Regency/City Region which is taken over by the Central Government and the provincial region. There is an assumption that the granting of authority only to the Provincial Government of the Region is not in accordance with the purpose of granting the broadest possible autonomy to the Regions which is directed to accelerate the realization of people's welfare through service improvement, empowerment, and community participation. Moreover, an important substance of regional autonomy is the transfer of authority from the center to the regions politically and economically so that development and economic growth take place fairly and evenly in the regions.

Many other problems can arise when almost all regional affairs are handled by the Central Government. Examples in the case of coastal databases and small islands whose authority is exercised by the Central Government which can actually be submitted to the Regency/City Government whose territory will be collected. On the other hand, the unequal distribution of authority can reduce the Regional Budget Revenue (Pendapatan Asli Daerah/PAD) and also when there are problems in the regions related to various policies that are handled by the Central Government, the handling must all be done by the Central Government. Interests oriented to political power and strengthening regional assets are problems that often arise in the implementation of regional autonomy. These interests are also affected by damage to the environment (ecology), population growth (demographics), fewer jobs (livelihoods), the political environment, changes in technology and changes in the level of commercialization (markets) which at some level causes conflict. Based on the explanation, the problem that will be discussed in this paper is how is the harmonization of the law regarding the management of the coastal sea area? and how is the synchronization of regulations regarding the management of coastal marine areas?

\section{RESEARCH METHOD}

This type of research is a normative legal research, using a conceptual approach and a statute approach [7]. The legal materials used in this study consist of primary, secondary and tertiary legal materials[8].The legal material that has been described in accordance with the main problem is then distributed, explored and then given an argument so that the whole forms a logically interconnected whole concerning the disclosure of logical rationale and ontological basis for the issuance of laws governing the management of the 
coastal marine area and the laws of the local government governing management of coastal marine areas.

\section{DISCUSSION}

\section{Harmonization of the Law regarding the Management of the Coastal Sea Area}

Indonesia is committed to harmonizing rules and policies to support industrial competitiveness and ensure close coordination of policy makers between ministries and institutions related to local government [9]. Efforts to harmonize the legal system with regard to imbalances and differences in the elements of the legal system are carried out by eliminating the imbalance and making adjustments to the different elements of the legal system. This view is in accordance with Zaphitiou's opinion that harmonization is to conduct regulation through unification efforts, by bringing regulations and policy coordination closer (harmonization is short of unification and consists in the approximation of rules and coordination of polices) [10].

The essence and legal character of the authority of the management of the sea area with regard to the concepts of constitutional law and administrative law. In this concept, the legal norms of government become the parameters used in the use of the authority exercised by organs or government bodies. This is certainly related to legal liability for the use of governmental authority itself. The parameters used in the use of that authority are legal compliance or legal non-compliance, so that if the use of authority is carried out in an "improper illegal" manner, the authorized government agency must be held responsible [11]. Starting from the component of authority in the concept of public law as stated above, the legal character in relation to the authority to manage maritime areas is related to the determination of the territorial boundaries of state authority. The determination of the authority's boundary is related to the concept of sovereignty both to the concept of state sovereignty (jurisdiction) and sovereignty rights of a country.

Indonesia and nine other ASEAN members are entering a very tough competition in the economic field [12]. In the management of sea areas, aspects of the legal structure, for example, there are various institutions involved (both directly and indirectly) with various authorities based on the laws and regulations made by each sector with the authority to regulate and manage their own government affairs. In addition, the substance of these laws and regulations is also sectoral with certain fields resulting in the emergence of conflicts of authority in the implementation of the tasks and authority of the institution itself and on the other hand also with regard to culture which in the concept of sea area management by indigenous peoples is known with the concept of customary rights.
The three components of the legal system mentioned above are interrelated with influencing one another, especially in terms of the authority relationship between the central and regional governments, one of which is in the field of management of marine and coastal resources. Understanding these basic problems becomes very important in relation to the concept of regulating authority in the management of the sea area. In this section, the analysis of the nature and legal character of the authority in the management of the sea area includes, among others:

1. authority for the management of marine spatial planning;

2. licensing authority; and

3. authority for supervision and law enforcement.

Of the several laws analyzed in relation to the regulation of the authority to manage the sea area, in the framework of providing legal certainty in the regulation of authority relating to sea spatial planning, there are 2 (two) important underlying factors, namely:

1. aspects of authority; and

2. aspects of planning.

The constitutionality of the authority relationship in the regulation of sea spatial planning from the normative aspect is placed in the authority relationship between the central government and regional governments in the utilization of the sea area and the natural resources contained therein. Therefore, it is necessary to provide clarity on the pattern of regulation of the management authority itself, especially relating to sources and procedures for obtaining authority in the management of the sea area as well as its regulation in sectoral laws so as to provide legal clarity, especially regarding the regulation of management area boundaries and spatial planning in the sea area. Meanwhile, from the aspect of planning in relation to spatial planning in the sea area, so that today it still creates conflict and legal vacuum considering the sea spatial planning is not explicitly regulated, so that a form of regulation that can be used as a reference in the regulation is needed. Spatial planning is important because it is related to the boundaries of the planning area, especially in the boundaries of the sea area which are the limits of regional authority. The boundary of the planning area is also a juridical consequence in which the region is given the authority to manage resources in the sea area.

Based on the description, in responding to regional needs related to the authority of spatial planning, certainly in the future it is necessary to harmonize legislation relating to the management of coastal sea areas in order to avoid multiple interpretations in their implementation, especially in the formation of regional regulations in this case concerning the legality of planning documents in the form RTRW with RZWP3K both concerns the 
implementation of institutional coordination functions and mechanisms by the regions in spatial planning and management of sea areas. Thus, in other words, in order to fill the legal vacuum in efforts to regulate sea areas, namely the concept of management of sea areas in relation to spatial arrangements for the regions, the legal basis that can be used as a source of authority for marine spatial regulation is to refer to Law Number 27 Year 2007 which has been revised into Law Number 1 Year 2014 and Law Number 26 Year 2007 with due regard to the pattern of authority arrangements as regulated in Law Number 32 Year 2004 which has been revised to Law Number 23 Year 2014. With regard to the autonomy of resource management the autonomy of the management of marine area resources for regions that includes the authority of permit services still raises legal issues both horizontally and vertically. In addition, conflicts relating to clarity regarding the source and how to obtain authority.

Related to the regulation of authority especially the authority to permit the management of natural resources in the sea area, among the laws and regulations also do not explicitly regulate licensing authority as a form of regional authority. Such arrangements in implementation often lead to conflicting norms, especially in the relationship between the Government and regional governments. Referring to the mindset in the concept of the legal framework governing authority in the management of the sea area stated above, by taking into account the analysis and study of sectoral laws in relation to the concept and pattern of regulating the management authority itself, several parameters can be used as references in regulating the authority of the management of sea areas which aims to minimize the potential for conflicting authority and conflicting norms in sectoral laws. The parameters referred to include the following:

a) Legal norms or norms as a basis in the formulation of norms based on norm theory;

b) The use of legal concepts relating to the theory of authority and concepts relating to the tanteng theory of the right to control the state;

c) The main legal principles relating to the principle of state control over natural resources and the principles of regional development and restructuring in the management of sea areas.

Of the three elements above, legal norms or norms as the basis in the formulation of norms in sectoral laws must be based and/or may not conflict with theories about norms. Legal norms contain a series of propositions or concepts, therefore to be able to explain the norm must be based on legal concepts. The concept of law is useful in relation to the application of law, among others regarding the interpretation of law, legal vacuum, antinomy, and vague norms (vege norm).

In the end in relation to the concept of authority, especially related to government authority, in the formulation of management authority in the sea area, it is necessary to pay attention to government norms that contain the principles and principles of governance. Thus, the entire process in regulating the authority to manage the sea area should pay attention to the elements or parameters mentioned above. In relation to the regulation of the authority to manage the sea area, the legal framework regulates the authority to manage the sea area.

The management concept intended here is related to the legal aspects in terms of control, utilization and use as well as the allocation of natural resources themselves. The legal aspects of management include two important issues namely the Concept relating to management rights and the Concept relating to the ownership rights that accompany it.

Legal aspects of management regarding concepts relating to ownership rights attached to them. This is certainly inseparable from the constitutional notion of state control over natural resources both earth, water, and natural resources contained therein as affirmed in the provisions of Article 33 paragraph (3) of the 1945 Constitution of the Republic of Indonesia. The source of control or ownership was born known as "the domein principle", which means ownership. This means that the state is the owner of the land, because it has all the authority to carry out acts of ownership (eigensdaad) [13].

\section{Synchronization of Regulations regarding the Management of Coastal Marine Areas}

L.M Lapian Gandhi's observations of legal practices in Indonesia are found in various sectors of regulation as a cause of the inconsistency, namely [14]:

a. The difference between various laws or regulations. In addition, the increasing number of regulations makes it difficult to know or know all of these regulations. Thus also, the provision which says that all people are considered to know all applicable laws is undoubtedly ineffective;

b. Conflict between the law and its implementing regulations;

c. The difference between statutory regulations and the habits of government agencies. We know the various operational guidelines, namely the implementation instructions which are even contrary to the laws and regulations that will be implemented. 
d. Difference between statutory regulations and jurisprudence and the Supreme Court Circular;

e. Conflicting policies of central government agencies;

f. Differences between Central and Regional government policies;

g. The difference between the legal provisions and the formulation of certain definitions; and

h. Conflict between the authority of government agencies due to the division of authority which is not systematic and clear.

Asynchronous in law includes the adjustment of laws and regulations, government decisions, decisions to increase legal unity, legal certainty, justice and comparability, usefulness and legal clarity, without burying and sacrificing legal pluralism if needed [15]. In reviewing legislation related to each other with other legislation that is why synchronization and harmonization are needed as an effort to: prevent and control functions of legal disharmony. Harmonization in law is to prevent legal disharmony. Harmonization in law is to prevent legal disharmony, what can be done is by making legal discoveries (legal interpretation and construction), legal reasoning and giving rational arguments.

In the current era of regional autonomy, there have been fundamental changes to the relationship between the central government and regional governments in the Unitary State of the Republic of Indonesia, including regional authority over the management of coastal marine areas and small islands. Changes in authority between the government and regional governments in the management of coastal marine areas and small islands which have implications for the need for legal harmonization between the Regional Government Law and the Management for the Coastal Sea and Small Islands Law, due to all relevant laws and regulations and regulates the management of the coastal areas of the Coast and Small Islands.

From the aspect of forming laws and regulations with the many laws and regulations related to the management of coastal sea areas, it turns out that the shape and format are very diverse. This is due to various legal products stipulated in different time periods, community situations and states. The condition of the community at the time of the formulation of a provision greatly affects the existence of a regulation, even a set of laws and regulations, usually caused by the demands of the community at that time both at the local level and the general public in the frame of the Unitary State of the Republic of Indonesia.

Indonesia is also a scattered archipelago in the world consisting of around 17,5082 islands with a sea area of around 5.8 million $\mathrm{km}^{2}$ and a line stretch of $81,000 \mathrm{~km}^{2}$. Most of the islands are small islands that have a wealth of natural resources and environmental services that are very potential for economic development [16]. Sea is one of the sources of wealth of a country, because it saves natural resources very much, be it fish, seaweed, rocks, coral, and others. One of the lucky countries by the grace of the god associated with the marine area is Indonesia [17]. Some coastal areas in Indonesia have quite high potential and strategic fishing areas so that inevitably the main livelihood for the people who live mainly in coastal areas is by fishing [18]. Located in the world coral triangle area, the Indonesian sea is rich in a variety of marine biota such as fish and coral reefs. Not surprisingly, Indonesia is one of the largest fish producers in the world, including for reef fish species. As a strategic commodity, reef fishing is one of the most cultivated by our fishermen [19].

The coming into effect of Law No. 1 Year 2014 concerning Management of coastal marine areas and small islands stipulated in 2014 aims to reaffirm efforts to manage natural resources by the government while affirming the existence of Article 33 paragraph (3) of the 1945 Constitution of the Republic of Indonesia. However, in the practice has not been able to answer some of the problems and legal needs in the management of coastal marine areas as outlined in the background. Vertically, the derivative regulations related to the Law on Management of Coastal Sea Areas and Small Islands in the form of Government Regulations and Ministerial Regulations have existed, but in reality they have not been able to overcome the various problems that occur.

The Law on the Management of Coastal Sea Areas and Small Islands is also not in line with the new Regional Government Law, it can be seen that in the Law on the Management of Coastal Sea Areas the authority of Regency/City Governments still exists but in the new Regional Government Law the authority of the Government Regency/City Region is abolished. The regency/city authority has been removed because it has many problems. This means that the new Regional Government Law removes the specialist Management of the Coastal Marine Area. Besides that, the Law on Management of Marine Areas is in a different regime from the new Regional Government Law. Therefore, the writer's suggestion needs to immediately formulate a draft regulation of coastal marine management that is in line with the new Local Government Law.

The political consensus of regional autonomy based on Law Number 32 Year 2004, the characteristics of the relationship between the center and the regions took place in a decentralized manner, where the regions were given broad authority to regulate and administer government affairs that were of regional interest. In the era of regional autonomy, it emphasized the 
decentralization system, which began and ended after the enactment of Law Number 23 Year 2014, apparently felt to be very much a problem such as the implementation of authority, institutions, finance, and supervision. This is caused by the relationship between the center and the regions not being transparent. Nonfunctioning coordination mechanisms do not have oversight in the area of licensing and weak sanctions are given.

\section{CONCLUSION}

The laws and regulations are not synchronous, which means that they are not in harmony. The disharmony is very influential on the relationship of governmental authority. Because the relationship between the Government and the Regional Government should be synergized with each other in: (a) Carrying out tasks that have been attributed to the legislation, (b) Utilization of natural resources, (c) Granting of licenses, (d) Distribution of Results, (e) Determination of boundaries the region. As for the efforts taken, the government immediately made a norm as mandated in Law No. 23 Year 2014. Which then established the Regional Regulation. The substance of the PP and Perda emphasizes the portion of the Regency/City.

\section{REFERENCES}

1. Astawa, I. G. P., \& Na'a, S. (2009). Memahami ilmu negara dan teori Negara. Rafika Aditama: Bandung.

2. Prajudi, A. (1981). Hukum Administrasi Negara (State Administrative Law), Ghalia Indonesia, Jakarta, 29.

3. Philipus, M. H. (2011). Hukum Administrasi dan Tindak Pidana Korupsi (Administrative Law and Corruption Crime), Gadjah Mada University Press, Yogyakarta, 10.

4. Philipus, M. H. Tentang Wewenang (About Authority), paper, Universitas Airlangga, Surabaya, 1.

5. Muhammad, A. S. (2015). Sentralisasi dalam UU Nomor 23 Tahun 2014 tentang Pemerintahan Daerah (Centralization in Law Number 23 Year 2014 concerning Regional Government), delivered at the focus group discussion "Inventory Issues Law No.23 of 2014 concerning Regional Government" organized by the Association of Regency Governments throughout Indonesia (Asosiasi Pemerintah Kabupaten seluruh Indonesia/APKASI). Jakarta.

6. Achmad, R. (2011). Peraturan PerundangUndangan Sebagai Sarana Hukum Penyelenggaraan Negara (Legislation as a Means of State Administration), Professor's Oration, 6.
7. Peter, M. M. (2003). Penelitian Hukum (Legal Reaearch), Prenada Media, Jakarta.

8. Roni, H. S. (1998). Metodologi Penelitian Hukum dan Jurimetri (Legal and Jurimetry Research Methodology), Penerbit Ghalia Indonesia Jakarta, 125.

9. Thamrin, H. \& Kadarudin. (2019). Indonesia in the industrial revolution era 4.0: challenges or threats?. International Management Journal January-June 2019, 46.

10. Zaphiriou, G. A. (1990). Harmonization of Private Rules Between Civil and Common Law Jurisdictions. The American Journal of Comparative Law, 71-97.

11. Djatmiati, T. S. (2004). Prinsip Izin Usaha Industri di Indonesia(Doctoral dissertation, UNIVERSITAS AIRLANGGA). 62-63.

12. Thamrin, H. \& Kadarudin. (2017). ASEAN Single Market and Challenges for Mirco, Small, and Medium Enterprises Product in Indonesia. JL Pol'y \& Globalization, 61, 9 .

13. Bagir, M. (2004). Menyongsong Fajar Otonomi Daerah (Welcoming of Regional Autonomy), Pusat Studi Hukum UII, Yogyakarta, 230.

14. Yuliandri. (2011). Asas-Asas Pembentukan Peraturan Perundang-Undangan yang Baik (Principles for the Establishment of Good Legislation), PT Raja Garfindo Persada Jakarta, 71.

15. Wirgakusuma, H. M. (1996). Perumusan Harmonisasi Hukum tnetang Metodologi Harmonisasi Hukum (Formulation of Legal Harmonization regarding the Law Harmonization Methodology), National Legal Development Agency, Department of Justice, Jakarta, 30.

16. Farida, P. (2013). Dimensi Hukum Pulau-Pulau Kecil di Indonesia (The Legal Dimension of Small Islands in Indonesia), Rangkang Education Yogyakarta, 1.

17. Asis, A. S., \& Ilyas, A. (2016). Strategic policy of the government of Indonesia In the field of maritime and fisheries affairs. International Journal of Scientific and Research Publications, 6, 238-43.

18. Asis, A. S., \& Ilyas, A. (2017). Hak-Kewajiban Nelayan dan Kelompok Nelayan Menurut UU RI Nomor 7 Tahun 2016 (Rights and Obligations of Fishermen and Fishermen Groups According to Law No. 7 Year 2016), Jurnal Hukum “Justitia”, 5(1):53

19. Asis, A., Sampurno, S., Ilyas, A., Indrawati, D., \& Muin, A. M. (2018). Persoalan hukum nelayan dan kelompok nelayan di kabupaten takalar. The Juris, 2(2), 175-186. 